\title{
Article \\ Selective Extraction of Platinum(IV) from the Simulated Secondary Resources Using Simple Secondary Amide and Urea Extractants
}

\author{
Yuki Ueda ${ }^{1,2, *(\mathbb{D}}$, Shintaro Morisada ${ }^{3}$, Hidetaka Kawakita $^{3}{ }^{(\mathbb{D}}$ and Keisuke Ohto ${ }^{3}$ (i) \\ 1 Materials Sciences Research Center, Japan Atomic Energy Agency, Tokai, Ibaraki 391-1195, Japan \\ 2 Advanced Science Research Center, Japan Atomic Energy Agency, Tokai, Ibaraki 391-1195, Japan \\ 3 Department of Chemistry and Applied Chemistry, Faculty of Science and Engineering, Saga University, \\ 1-Honjo, Saga 840-8502, Japan; morisada@cc.saga-u.ac.jp (S.M.); kawakita@cc.saga-u.ac.jp (H.K.); \\ ohtok@cc.saga-u.ac.jp (K.O.) \\ * Correspondence: ueda.yuki@jaea.go.jp; Tel.: +81-29-284-3960
}

Citation: Ueda, Y.; Morisada, S.; Kawakita, H.; Ohto, K. Selective Extraction of Platinum(IV) from the Simulated Secondary Resources Using Simple Secondary Amide and Urea Extractants. Separations 2021, 8, 139. https://doi.org/10.3390/ separations 8090139

Academic Editor: Ernesto Reverchon

Received: 7 August 2021

Accepted: 30 August 2021

Published: 1 September 2021

Publisher's Note: MDPI stays neutral with regard to jurisdictional claims in published maps and institutional affiliations.

Copyright: (c) 2021 by the authors. Licensee MDPI, Basel, Switzerland. This article is an open access article distributed under the terms and conditions of the Creative Commons Attribution (CC BY) license (https:/ / creativecommons.org/licenses/by/ $4.0 /)$.

\begin{abstract}
The recycling of rare metals such as platinum $(\mathrm{Pt})$ from secondary resources, such as waste electronic and electrical equipment and automotive catalysts, is an urgent global issue. In this study, simple secondary amides and urea, $N$-(2-ethylhexyl)acetamide, $N$-(2-ethylhexyl)octanamide, and 1-butyl-3-(2-ethylhexyl)urea, which selectively extract Pt(IV) from a simulated effluent containing numerous metal ions, such as in an actual hydrometallurgical process, were synthesized and achieved efficient $\mathrm{Pt}(\mathrm{IV})$ stripping using only water. Comparison of $\mathrm{Pt}(\mathrm{IV})$ extraction behavior with a tertiary amide without $\mathrm{N}-\mathrm{H}$ moieties suggests that the secondary amides and urea extractants effectively use hydrogen bonding to the hexachloroplatinate anion by N-H moieties. Examining the conditions for the third phase formation revealed that the secondary amide extractant with the longest alkyl chain can be used in the extraction process for a long time without forming any third phase, despite its lower $\mathrm{Pt}(\mathrm{IV})$ extraction capacity. The practical trial with simple compounds developed in this study should contribute to the development of Pt separation and purification processes.
\end{abstract}

Keywords: platinum group metal; extraction; secondary amide; urea; hydrogen bond; third phase; secondary resources; simulated waste liquid; waste electrical and electronic equipment; stripping

\section{Introduction}

Platinum group metals (PGMs), namely, Pd, $\mathrm{Pt}, \mathrm{Rh}, \mathrm{Ir}, \mathrm{Ru}$, and Os, are in constant demand due to their excellent physical and chemical properties [1-3]. Notably, Pt has been widely used in jewelry goods, electronic devices, fuel cells, automobile exhaust catalysts, and various industrial fields $[1,2,4]$. However, there are future concerns about a decrease in demand in the exhaust catalyst field due to the shift from gasoline and diesel vehicles to electric vehicles. Moreover, the availability of $\mathrm{Pt}$ is limited to certain locations in Russia and South Africa [3,5]. Further, the amount of Fe and Au ore mined in 2019 were 48,000 and 200 tons, respectively, whereas Pt ore mined was only 3.6 tons [6]. Therefore, the recovery of PGMs including Pt from secondary resources, such as waste electrical and electronic equipment and spent catalysts, is an urgent issue. The refining of PGMs from aqueous acidic chloride media is commonly achieved by hydrometallurgical processes using the solvent extraction method for their separation and has been studied by several researchers [7-9]. The solvent extraction method has various advantages in industrial applications such as high capacity, high selectivity, room temperature operation, and relatively easy scale-up. Although the extraction of Pt by industrial extractants has been studied, more efficient extractants are required to stabilize the Pt supply and price.

Recently, the development of extractants for the selective extraction of $\mathrm{Pt}$ has been studied by various researchers $[7,8]$. Costa et al. studied the extraction of $\mathrm{Pt}(\mathrm{IV})$ using a 
series of $N, N^{\prime}$-dimethyl- $N, N^{\prime}$-dialkylmalonamides, and reported that $N, N^{\prime}$-dimethyl- $N, N^{\prime}-$ dibutylmalonamide was reported to extract the hexachloroplatinate anion $\left(\left[\mathrm{PtCl}_{6}\right]^{2-}\right)$ by means of two protonated carbonyl oxygen atoms [10-12]. Narita et al. reported that the extraction performance of the $\left[\mathrm{PtCl}_{6}\right]^{2-}$ using a tertiary amide-containing tertiary amine, i.e., $\mathrm{N}$-2-ethylhexyl-bis( $\mathrm{N}$-di-2-ethylhexyl-ethylamide)amine, as the extractant, was higher than that with commercially available tri-n-octylamine (TOA) [13]. Further, Tasker and coworkers have extensively investigated the extraction of anionic chloro-species, discovering a notable selectivity of a series of tripodal amide-containing tertiary amines for extracting $\left[\mathrm{PtCl}_{6}\right]^{2-}$ over a large excess of chloride anion $\left(\mathrm{Cl}^{-}\right)$[14-18]. These extractants all share the idea that not only relatively strong interactions in the inner-sphere but also the relatively weak interactions of the outer-sphere have been taken into account. Here, relatively weak interactions refer to hydrogen bonding $(4-60 \mathrm{~kJ} / \mathrm{mol})$ as opposed to relatively strong interactions such as coulombic interactions between ions $(5-300 \mathrm{~kJ} / \mathrm{mol})$ and coordination bonds between a metal ion and a ligand $(40-120 \mathrm{~kJ} / \mathrm{mol})[19,20]$. Low selectivity and suppression of back-extraction can result from an extremely strong affinity for metal ions [5,7-9]. Further, the development of a more convenient extractant is essential from a practical perspective.

In this study, we present conveniently prepared secondary amide and urea extractants for Pt(IV) separation from the simulated secondary resources (SSRs) containing numerous metal ions, as in the actual hydrometallurgical process. The secondary amide and urea extractants are synthesized from the reaction of a primary amine (2-ethylhexylamine) with acyl halide (acetyl chloride or $n$-octanoyl chloride) or an isocyanate (butyl isocyanate), both of which are inexpensive starting materials $[17,18,21-26]$. The advantages of the secondary amide and urea functional groups are that they provide an $\mathrm{N}-\mathrm{H}$ donor for hydrogen bond formation with the $\left[\mathrm{PtCl}_{6}\right]^{2-}$ anion and are stable under acidic solutions, which are the requirements adopted in hydrometallurgical separation processes [14,16-18,27-31]. Secondary amide and urea compounds form continuous intermolecular hydrogen bonds, which are expected to be an effective driving force for extracting $\left[\mathrm{PtCl}_{6}\right]^{2-}$ anion in an apolar solvent $[14,15,17,18]$. The extraction of $\mathrm{Ga}(\mathrm{III})$ from the $\mathrm{HCl}$ solution by $\mathrm{N}-(2-$ ethylhexyl)acetamide has been investigated and the formation of hydrogen bonds to $\left[\mathrm{GaCl}_{4}\right]^{-}$and $\mathrm{H}_{2} \mathrm{O}$ has been reported [32]. Further, amide and urea compounds are completely incinerable at the end of the hydrometallurgical process due to their elemental composition $(\mathrm{C}, \mathrm{H}, \mathrm{N}, \mathrm{O})[32,33]$. In this study, simple amide and urea compounds were developed for the selective extraction of $\mathrm{Pt}(\mathrm{IV})$. To verify the $\mathrm{N}-\mathrm{H}$ moiety effect, a tertiary amide extractant without the $\mathrm{N}-\mathrm{H}$ moiety was also synthesized for comparison. Figure 1 represents the chemical structures and abbreviations of these four extractants. First, the effect of $\mathrm{HCl}$ concentration on the extraction performance of precious and base metals was investigated to preliminarily determine the extraction characteristics of these extractants synthesized in this study at lower metal ion concentrations. Then, to investigate the applicability of these extractants to the actual hydrometallurgical separation process, the extraction rate, $\mathrm{Pt}(\mathrm{IV})$ separation ability, the conditions for the third phase formation, and $\mathrm{Pt}(\mathrm{IV})$ stripping were examined. 
<smiles>CCCCC(CC)CNC(C)=O</smiles>

$\mathrm{N}$-(2-Ethylhexyl)acetamide MonoAA<smiles>CCCCNC(=O)NCC(CC)CCCC</smiles>

1-Butyl-3-(2-ethylhexyl)urea MonoBU<smiles>CCCCCCCC(=O)NCC(CC)CCCC</smiles>

$\mathrm{N}$-(2-Ethylhexyl)octanamide MonoOA<smiles>CCCCC(CC)CN(CC(CC)CCCC)C(C)=O</smiles>

$\mathrm{N}, \mathrm{N}$-Bis(2-ethylhexyl)acetamide BisAA

Figure 1. Representation of the chemical structures and abbreviations of the extractants.

\section{Materials and Methods}

\subsection{Materials}

TOA (Tokyo Chemical Industry Co., Ltd. (TCI), Tokyo, Japan; purity, $>97.0 \%$ ), tri- $n$ butyl phosphate (TBP, FUJIFILM Wako Pure Chemical Corporation (Wako), Osaka, Japan; purity, >98.0\%), dibutyl carbitol (DBC, Sigma-Aldrich Japan, Tokyo, Japan; purity, >99\%), methyl isobutyl ketone (MIBK, TCI; purity, >99.5\%), n-dodecane (Wako; purity, >99.0\%), 2-ethylhexanol (Wako; purity, >98.0\%), chloroform (Wako; purity, >99.0\%), 2-ethylhexylamine (Sigma-Aldrich Japan, Tokyo, Japan; purity, >98\%), di(2-ethylhexyl)amine (Sigma-Aldrich Japan, Tokyo, Japan; purity, >99\%), acetyl chloride (Wako; purity, >98.0\%), n-octanoyl chloride (TCI; purity, >99.0\%), butyl isocyanate (TCI; purity, $>98.0 \%$ ), $\mathrm{HAuCl}_{4} \cdot 4 \mathrm{H}_{2} \mathrm{O}$ (Wako; purity, $>99.9 \%$ ), $\mathrm{H}_{2} \mathrm{PtCl}_{6} \cdot 6 \mathrm{H}_{2} \mathrm{O}$ (Wako; purity, >98.5\%), $\mathrm{IrCl}_{3}$ (Wako; purity, >97.0\%), $\mathrm{RhCl}_{3} \cdot 3 \mathrm{H}_{2} \mathrm{O}$ (Wako; purity, >99.5\%), $\mathrm{FeCl}_{3} \cdot 6 \mathrm{H}_{2} \mathrm{O}$ (Wako; purity, >99.0\%), $\mathrm{CuCl}_{2} \cdot 2 \mathrm{H}_{2} \mathrm{O}$ (Wako; purity, $>99.9 \%$ ) $\mathrm{NiCl}_{2} \cdot 6 \mathrm{H}_{2} \mathrm{O}$ (Wako; purity, 99.9\%), $\mathrm{CoCl}_{2} \cdot 6 \mathrm{H}_{2} \mathrm{O}$ (Wako; purity, $>99.5 \%$ ), $\mathrm{ZnCl}_{2}$ (Wako; purity, >98.0\%), and $\mathrm{PbCl}_{2}$ (Wako; purity, 99.0\%) were purchased and used without further purification.

\subsection{Synthesis of N-(2-Ethylhexyl)acetamide (MonoAA)}

MonoAA was synthesized by modifying the procedure of Simon et al. [21-25]. Acetyl chloride $(25.6 \mathrm{~g}, 0.33 \mathrm{~mol})$ was mixed with chloroform $\left(\mathrm{CHCl}_{3}, 50 \mathrm{~mL}\right)$ in an ice-water bath, and the solution was carefully added to a solution of 2-ethylhexylamine (40.0 $\mathrm{g}$, $0.31 \mathrm{~mol})$ and triethylamine $\left(\mathrm{Et}_{3} \mathrm{~N}, 62.6 \mathrm{~g}, 0.62 \mathrm{~mol}\right)$ in $\mathrm{CHCl}_{3}(150 \mathrm{~mL})$ using a dropping funnel. The reacting solution was stirred $(150 \mathrm{rpm})$ for $12 \mathrm{~h}$ at $40{ }^{\circ} \mathrm{C}$ and the reaction was monitored using thin-layer chromatography (TLC); the resulting solution was transferred to a separation funnel. The chloroform layer was washed three times with saturated sodium hydrogen carbonate $\left(\mathrm{NaHCO}_{3}\right)$ aqueous solution $(50 \mathrm{~mL})$ followed by another three-time wash with distilled water $(50 \mathrm{~mL})$. The resulting organic solution was separated and dried over anhydrous magnesium sulfate $\left(\mathrm{MgSO}_{4}\right)$. The product was obtained as a yellow oil (51.1 g, 96.3\% yield) after filtration and evaporation of the solvent under reduced pressure. The compound was characterized using proton nuclear magnetic resonance $\left({ }^{1} \mathrm{H}\right.$ NMR) (JNM-GX300, JEOL Ltd., Tokyo, Japan) and IR (IRAffinity-1, Shimadzu Co., Kyoto, Japan) spectroscopies: $\mathrm{TLC}\left(\mathrm{SiO}_{2}\right.$; chloroform $/$ methanol = 9:1): $R_{\mathrm{f}}=0.69$; ${ }^{1} \mathrm{H}$ NMR (400 MHz, $\left.\mathrm{CDCl}_{3}, \mathrm{TMS}\right): \delta 0.90\left(6 \mathrm{H}, \mathrm{m},-\mathrm{CH}\left(\mathrm{CH}_{2}\right)_{3}-\mathrm{CH}_{3}\right.$ and $\left.-\mathrm{CHCH}_{2}-\mathrm{CH}_{3}\right)$, $\delta$ 1.28-1.43 (9H, m, $-\mathbf{C H}\left(\mathbf{C H}_{2}\right)_{3}-\mathrm{CH}_{3}$ and $\left.-\mathrm{CHCH}_{2}-\mathrm{CH}_{3}\right), \delta 2.00\left(3 \mathrm{H}, \mathrm{s},-\mathrm{NH}-\mathrm{CO}-\mathrm{CH}_{3}\right)$, $\delta 3.19\left(2 \mathrm{H}, \mathrm{t},-\mathrm{NH}-\mathrm{CH}_{2}-\mathrm{CH}-\right)$, and $\delta 5.60\left(1 \mathrm{H}, \mathrm{br},-\mathrm{NH}-\mathrm{CO}-\mathrm{CH}_{3}\right)$; IR (attenuated total reflectance $\left.(\mathrm{ATR}), \mathrm{SeZn}, \mathrm{cm}^{-1}\right) 1558\left(\delta_{\mathrm{N}-\mathrm{H}}\right), 1647\left(v_{\mathrm{C}=\mathrm{O}}\right), 2927\left(v_{-\mathrm{CH} 2}\right), 2958\left(v_{-\mathrm{CH}}\right)$, 
$3088\left(v_{\mathrm{N}-\mathrm{H}}\right)$, and $3290\left(v_{\mathrm{N}-\mathrm{H}}\right)$. The corresponding ${ }^{1} \mathrm{H}$ NMR and IR spectra are depicted in Figures S1 and S2 in the Supplemental Material.

\subsection{Synthesis of N-(2-Ethylhexyl)octanamide (MonoOA)}

MonoOA was synthesized by modifying the procedure of Simon et al. [21-25]. Octanoyl chloride $(52.9 \mathrm{~g}, 0.33 \mathrm{~mol})$ was mixed with chloroform $\left(\mathrm{CHCl}_{3}, 50 \mathrm{~mL}\right)$ in an icewater bath, and the solution was carefully added to a solution of 2-ethylhexylamine (40.0 g, $0.31 \mathrm{~mol})$ and $\mathrm{Et}_{3} \mathrm{~N}(62.6 \mathrm{~g}, 0.62 \mathrm{~mol})$ in $\mathrm{CHCl}_{3}(150 \mathrm{~mL})$ using a dropping funnel. The reacting solution was stirred $(150 \mathrm{rpm})$ and heated to reflux for $12 \mathrm{~h}$ and the reaction was monitored using TLC. The resulting solution was purified in the same manner as described above. The product was obtained as a yellow oil ( $73.2 \mathrm{~g}, 92.5 \%$ yield) after filtration and evaporation. The compound was characterized using ${ }^{1} \mathrm{H}$ NMR and IR spectroscopies: TLC $\left(\mathrm{SiO}_{2}\right.$; chloroform $/$ methanol = 9:1): $R_{\mathrm{f}}=0.61 ;{ }^{1} \mathrm{H}$ NMR $\left(400 \mathrm{MHz}, \mathrm{CDCl}_{3}, \mathrm{TMS}\right): \delta 0.89(9 \mathrm{H}$, $\mathrm{m},-\mathrm{CH}\left(\mathrm{CH}_{2}\right)_{3}-\mathrm{CH}_{3},-\mathrm{CHCH}_{2}-\mathrm{CH}_{3}$ and $\left.-\left(\mathrm{CH}_{2}\right)_{6}-\mathrm{CH}_{3}\right), \delta 1.28-1.42\left(17 \mathrm{H}, \mathrm{m},-\mathrm{CH}\left(\mathrm{CH}_{2}\right)_{3}-\right.$ $\mathrm{CH}_{3},-\mathrm{CHCH}_{2}-\mathrm{CH}_{3}$ and $\left.-\left(\mathrm{CH}_{2}\right)_{2}\left(\mathbf{C H}_{2}\right)_{4}-\mathrm{CH}_{3}\right), \delta 1.62\left(2 \mathrm{H}, \mathrm{m},-\mathrm{NH}-\mathrm{CO}-\left(\mathrm{CH}_{2}\right)\left(\mathbf{C H}_{2}\right)-\right), \delta$ $2.17\left(2 \mathrm{H}, \mathrm{t},-\mathrm{NH}-\mathrm{CO}-\left(\mathbf{C H}_{2}\right)\left(\mathrm{CH}_{2}\right)-\right), \delta 3.20\left(2 \mathrm{H}, \mathrm{t},-\mathrm{NH}-\mathbf{C H}_{2}-\mathrm{CH}-\right)$, and $\delta 5.49(1 \mathrm{H}, \mathrm{br},-\mathbf{N H}-$ $\left.\mathrm{CO}-\mathrm{CH}_{2}-\right)$; IR (ATR, SeZn, cm $\left.{ }^{-1}\right) 1556\left(\delta_{\mathrm{N}-\mathrm{H}}\right), 1641\left(v_{\mathrm{C}=\mathrm{O}}\right), 2926\left(v_{-\mathrm{CH} 2-}\right), 2956\left(v_{-\mathrm{CH}}\right)$, $3084\left(v_{\mathrm{N}-\mathrm{H}}\right)$, and $3290\left(v_{\mathrm{N}-\mathrm{H}}\right)$. The corresponding ${ }^{1} \mathrm{H}$ NMR and IR spectra are depicted in Figures S3 and S4 in the Supplemental Material.

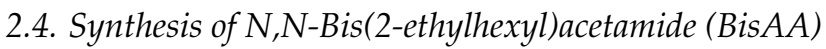

BisAA was synthesized by modifying the procedure of Simon et al. [21-25]. Acetyl chloride $(48.8 \mathrm{~g}, 0.62 \mathrm{~mol})$ was mixed with chloroform $\left(\mathrm{CHCl}_{3}, 50 \mathrm{~mL}\right)$ in an ice-water bath, and the solution was carefully added to a solution of di(2-ethylhexyl)amine (50.0 g, $0.21 \mathrm{~mol})$ and $\mathrm{Et}_{3} \mathrm{~N}(126 \mathrm{~g}, 1.24 \mathrm{~mol})$ in $\mathrm{CHCl}_{3}(150 \mathrm{~mL})$ using a dropping funnel. The reacting solution was stirred $(150 \mathrm{rpm})$ and heated to reflux for $12 \mathrm{~h}$ and the reaction was monitored using TLC. The resulting solution was purified in the same manner as described above. The product was obtained as a yellow oil ( $50.7 \mathrm{~g}, 86.4 \%$ yield) after filtration and evaporation. The compound was characterized using ${ }^{1} \mathrm{H}$ NMR and IR spectroscopies: TLC $\left(\mathrm{SiO}_{2}\right.$; chloroform/methanol = 9:1): $R_{\mathrm{f}}=0.54 ;{ }^{1} \mathrm{H} \mathrm{NMR}\left(400 \mathrm{MHz}, \mathrm{CDCl}_{3}, \mathrm{TMS}\right): \delta$ 0.84-0.92 (12H, m, $-\mathrm{CH}\left(\mathrm{CH}_{2}\right)_{3}-\mathrm{CH}_{3}$ and $\left.-\mathrm{CHCH}_{2}-\mathrm{CH}_{3}\right), \delta 1.26\left(16 \mathrm{H}, \mathrm{m},-\mathrm{CH}\left(\mathrm{CH}_{2}\right)_{3}-\mathrm{CH}_{3}\right.$ and $\left.-\mathrm{CHCH}_{2}-\mathrm{CH}_{3}\right), \delta 2.09\left(3 \mathrm{H}, \mathrm{s},-\mathrm{NH}-\mathrm{CO}-\mathrm{CH}_{3}\right), \delta 3.13\left(2 \mathrm{H}, \mathrm{t},-\mathrm{NH}-\mathrm{CH}_{2}-\mathrm{CH}-\right)$, and $\delta 3.27\left(2 \mathrm{H}, \mathrm{m},-\mathrm{CH}\left(\mathrm{CH}_{2}\right)_{3}-\mathrm{CH}_{3}\right)$; IR (ATR, SeZn, $\left.\mathrm{cm}^{-1}\right) 1647\left(v_{\mathrm{C}=\mathrm{O}}\right), 2927\left(v_{-} \mathrm{CH} 2-\right)$, and $2959\left(v_{-} \mathrm{CH} 3\right)$. The corresponding ${ }^{1} \mathrm{H}$ NMR and IR spectra are depicted in Figures S5 and S6 in the Supplemental Material.

\subsection{Synthesis of 1-Butyl-3-(2-ethylhexyl)urea (MonoBU)}

MonoBU was synthesized according to a published procedure $[17,18,21,26]$ with several minor modifications [34]. The compound was characterized using ${ }^{1} \mathrm{H}$ NMR and IR spectroscopies: TLC $\left(\mathrm{SiO}_{2}\right.$; chloroform/methanol = 9:1): $R_{\mathrm{f}}=0.64 ;{ }^{1} \mathrm{H} \mathrm{NMR}(400 \mathrm{MHz}$, $\left.\mathrm{CDCl}_{3}, \mathrm{TMS}\right): \delta 0.90\left(9 \mathrm{H}, \mathrm{m},-\mathrm{CH}_{2}-\mathbf{C H}_{3}\right), \delta 1.27\left(10 \mathrm{H}, \mathrm{m},-\mathrm{CH}\left(\mathbf{C H}_{2}\right)\left(\mathbf{C H}_{2}\right)_{3}-\mathrm{CH}_{3}\right.$ and $\left.\left(\mathbf{C H}_{2}\right)_{2}-\mathrm{CH}_{3}\right), \delta 1.46\left(3 \mathrm{H}, \mathrm{q},-\mathbf{C H}\left(\mathbf{C H}_{2}\right)-\mathrm{CH}_{3}\right), \delta 3.08\left(2 \mathrm{H}, \mathrm{t},-\mathrm{NH}-\mathbf{C H}_{\mathbf{2}}-\mathrm{CH}-\right), \delta 3.16(2 \mathrm{H}, \mathrm{q}$, $\left.-\mathrm{NH}-\mathrm{CH}_{2}-\left(\mathrm{CH}_{2}\right)_{2}-\mathrm{CH}_{3}\right), \delta 4.91\left(1 \mathrm{H}, \mathrm{br},-\mathrm{NH}-\mathrm{CH}_{2}-\mathrm{CH}-\right)$, and $\delta 4.97\left(1 \mathrm{H}, \mathrm{br},-\mathrm{NH}-\mathrm{CH}_{2}-\right.$ $\left.\left(\mathrm{CH}_{2}\right)_{2}-\mathrm{CH}_{3}\right)$; IR $\left(\mathrm{ATR}, \mathrm{SeZn}, \mathrm{cm}^{-1}\right) 1570\left(\delta_{\mathrm{N}-\mathrm{H}}\right), 1629\left(v_{\mathrm{C}=\mathrm{O}}\right), 2927\left(v_{-\mathrm{CH} 2}\right), 2958\left(v_{-} \mathrm{CH} 3\right)$, and $3344\left(v_{\mathrm{N}-\mathrm{H}}\right)$.

\subsection{Metal Ion Extraction Procedure}

The extraction experiments were performed using the batch method. All experiments for extracting metal ions were conducted in a metal ion coexistent system. For the aqueous phase with lower metal ion concentration, metal ion solutions were prepared by dissolving each metal chloride salt $\left(\mathrm{HAuCl}_{4} \cdot 6 \mathrm{H}_{2} \mathrm{O}, \mathrm{H}_{2} \mathrm{PtCl}_{6} \cdot 6 \mathrm{H}_{2} \mathrm{O}, \mathrm{PdCl}_{2}, \mathrm{RhCl}_{3} \cdot 3 \mathrm{H}_{2} \mathrm{O}, \mathrm{IrCl}_{3}\right.$, $\left.\mathrm{FeCl}_{3} \cdot 6 \mathrm{H}_{2} \mathrm{O}, \mathrm{CuCl}_{2} \cdot 2 \mathrm{H}_{2} \mathrm{O}, \mathrm{NiCl}_{2} \cdot 6 \mathrm{H}_{2} \mathrm{O}, \mathrm{CoCl}_{2} \cdot 6 \mathrm{H}_{2} \mathrm{O}, \mathrm{ZnCl}_{2}, \mathrm{PbCl}_{2}\right)$ in varying $\mathrm{HCl}$ concentrations to obtain a concentration of $0.1 \times 10^{-3} \mathrm{M}$. For SSRs, the aqueous phase of $2.0 \mathrm{M}$ $\mathrm{HCl}$ solution containing $0.274 \mathrm{M}(53.4 \mathrm{~g} / \mathrm{L}) \mathrm{Pt}(\mathrm{IV}), 8.24 \times 10^{-3} \mathrm{M}(1.58 \mathrm{~g} / \mathrm{L}) \mathrm{Ir}(\mathrm{III}), 0.115 \mathrm{M}$ 
(11.8 g/L) $\mathrm{Rh}(\mathrm{III})$, and $0.268 \mathrm{M}(17.0 \mathrm{~g} / \mathrm{L}) \mathrm{Cu}(\mathrm{II})$ was prepared by adding $\mathrm{H}_{2} \mathrm{PtCl}_{6} \cdot 6 \mathrm{H}_{2} \mathrm{O}$ (14.2 g), $\mathrm{IrCl}_{3}(0.246 \mathrm{~g}), \mathrm{RhCl}_{3} \cdot 3 \mathrm{H}_{2} \mathrm{O}(3.03 \mathrm{~g}), \mathrm{CuCl}_{2} \cdot 2 \mathrm{H}_{2} \mathrm{O}(4.57 \mathrm{~g})$, and concentrated $\mathrm{HCl}$ $(17.9 \mathrm{~mL})$ to a $100 \mathrm{~mL}$ volumetric flask and diluting with distilled water. The organic phase was prepared by dissolving the extractant in chloroform or a mixed solvent consisting of $n$-dodecane and 2-ethylhexanol to achieve a concentration of $0.1 \mathrm{M}$. Note that chloroform should not be used for practical processes due to its harmful property. However, chloroform was partly employed as a diluent for preliminary validation of extraction behavior by comparing with previous results. Equal volumes of both phases were shaken horizontally at $30^{\circ} \mathrm{C}$ and $150 \mathrm{rpm}$ for $3 \mathrm{~h}$. A temperature-controlled water bath was used to maintain the temperature during phase equilibration. After phase separation, the metal concentration in the aqueous phase was measured using inductively coupled plasma-atomic emission spectrometry (ICP-AES) (ICPS-8100, Shimadzu Co., Kyoto, Japan). Notably, the presence or absence of the third phase was visually confirmed. Further, 5.0 M HCl, 5.0 M nitric acid $\left(\mathrm{HNO}_{3}\right)$, water, $0.1 \mathrm{M}$ ammonia $\left(\mathrm{NH}_{3}\right)$, or $0.1 \mathrm{M}$ sodium hydroxide $(\mathrm{NaOH})$ aqueous solutions were used to strip the extracted $\mathrm{Pt}(\mathrm{IV})$ from the organic phase. The extraction and stripping percentages (\% Extraction and \%Stripping) of the metal ions were calculated using the following equations:

$$
\begin{gathered}
\% \text { Extraction }=\left\{\left([\text { Metal ion }]_{\mathrm{i}}-[\text { Metal ion }]_{\mathrm{e}}\right) /[\text { Metal ion }]_{\mathrm{i}}\right\} \times 100 \\
\% \text { Stripping }=\left\{[\text { Metal ion }]_{\mathrm{s}} /\left([\text { Metal ion }]_{\mathrm{i}}-[\text { Metal ion }]_{\mathrm{e}}\right) \times 100\right.
\end{gathered}
$$

where the subscripts i, e, and s denote the initial, equilibrium, stripping conditions, respectively. Notably, when the third phase is formed, \%Extraction refers to the percentage of metal ions removed from the aqueous phase, rather than the percentage of metal ions in the organic phase. Measurements of \% Extraction and \%Stripping were repeated three times, with standard errors of less than $5 \%$.

\section{Results and Discussion}

\subsection{Extraction from Lower Metal Concentration Effect of $\mathrm{HCl}$ Concentration}

The extraction behavior of the four extractants synthesized in this study for precious and base metals was investigated under lower metal concentration conditions. Figure 2 shows the effect of $\mathrm{HCl}$ concentration on the extraction percentage of metal ions by MonoAA, MonoOA, MonoBU, and BisAA. For comparison, the extraction results of PGM and base metal ions by MonoBU reported very recently are also shown in Figure 2c [34].

$\mathrm{Au}(\mathrm{III})$ was extracted almost quantitatively in all $\mathrm{HCl}$ concentrations by all extractants. In general, $\mathrm{Au}(\mathrm{III})$ is easily extracted by ketone and ether extractants in the hydrometallurgical separation process $[7,35]$. Therefore, we believe that these extractants, which are secondary amides, urea, and tertiary amides with carbonyl oxygen atoms, can easily extract $\mathrm{Au}(\mathrm{III})$.

At $\mathrm{HCl}$ concentration of $0.01-1.0 \mathrm{M}$, the order of extraction ability of $\mathrm{Pt}(\mathrm{IV})$ was MonoAA $>>$ MonoOA > MonoBU >> BisAA, whereas the order at $\mathrm{HCl}$ concentrations of 1.0-10 M was MonoAA > MonoOA $\approx$ MonoBU > BisAA. Interestingly, in the lower $\mathrm{HCl}$ concentration, $\mathrm{Pt}(\mathrm{IV})$ was hardly extracted by BisAA. However, $\mathrm{Pt}(\mathrm{IV})$ was extracted by MonoAA, MonoOA, and MonoBU in the lower $\mathrm{HCl}$ concentration, and the extraction behavior of $\mathrm{Pt}(\mathrm{IV})$ by MonoOA, MonoBU, and BisAA changes around $1.0 \mathrm{M} \mathrm{HCl}$ concentration. Further, there is no significant difference in the acidic conditions in which the carbonyl oxygen atoms of secondary amide, urea, and tertiary amide groups are protonated [36,37]. These carbonyl oxygen atoms are protonated at $\mathrm{HCl}$ concentrations above about 2.0 M $[15,38,39]$. In other words, in the extraction of $\mathrm{Pt}(\mathrm{IV})$ at low $\mathrm{HCl}$ concentration, these extractants are considered incapable of anion exchange reactions via coulombic interactions associated with the protonation of carbonyl oxygen atoms. Taken together, $\mathrm{Pt}(\mathrm{IV})$ is extracted only via hydrogen bonding interaction to $\left[\mathrm{PtCl}_{6}\right]^{2-}$ by N-H moieties of secondary amide and urea groups in the extraction of $\mathrm{Pt}(\mathrm{IV})$ from low $\mathrm{HCl}$ concentration 
by MonoAA, MonoOA, and MonoBU. Whereas, $\mathrm{Pt}(\mathrm{IV})$ is considered to be extracted by anion exchange reaction via coulombic interaction with protonation of carbonyl oxygen atoms in the extraction of $\mathrm{Pt}(\mathrm{IV})$ from high $\mathrm{HCl}$ concentration.

(a)

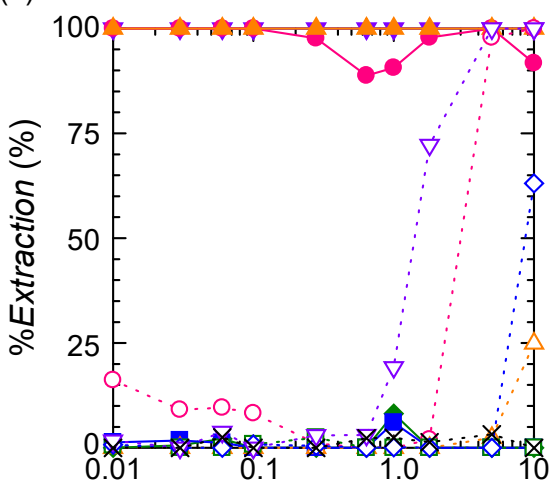

(c)

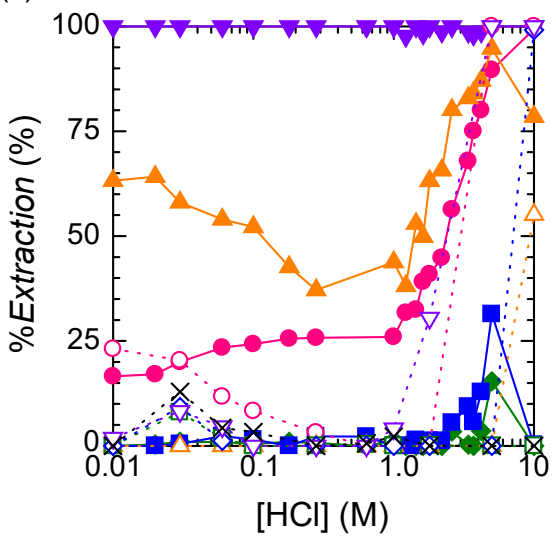

(b)

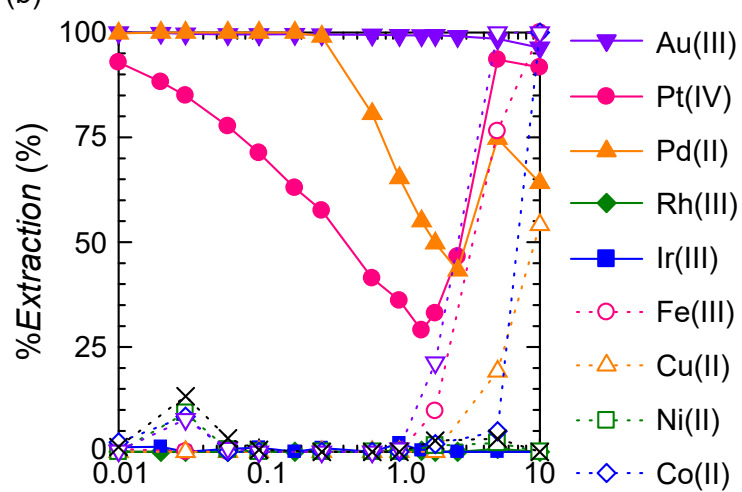

(d)

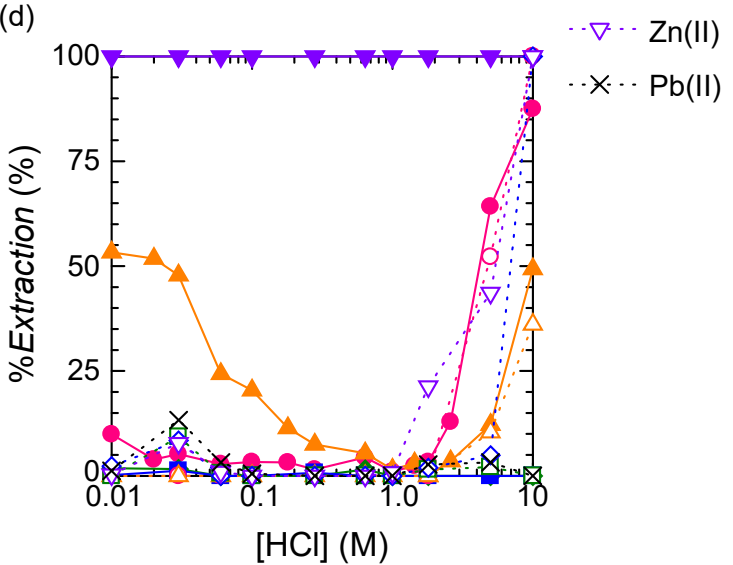

Figure 2. Effect of $\mathrm{HCl}$ concentration on the extraction percentage of metal ions by (a) MonoAA, (b) MonoOA, (c) MonoBU, and (d) BisAA. [Extractant $]_{\text {org, }}=1.0 \mathrm{M}$ in chloroform, [Pt(IV), Pd(II), Rh(III), Ir(III), $\mathrm{Fe}(\mathrm{IIII}), \mathrm{Cu}(\mathrm{II}), \mathrm{Ni}(\mathrm{II}), \mathrm{Co}$ (II), $\mathrm{Zn}$ (II), Pb(II) $]_{\mathrm{aq}, \mathrm{i}}=0.1 \times 10^{-3} \mathrm{M}$ each, $[\mathrm{HCl}]_{\mathrm{aq}, \mathrm{i}}=0.01-10 \mathrm{M}$.

For Pd(II) extraction by MonoAA, Pd(II) was almost quantitatively extracted in all $\mathrm{HCl}$ concentrations, whereas the $\mathrm{Pd}(\mathrm{II})$ extraction behavior by MonoOA, MonoBU, and BisAA exhibited a similar trend with minor differences in extraction ability. Concretely, the extraction percentage decreased with increasing $\mathrm{HCl}$ concentration at $0.01-1.0 \mathrm{M}$, and it increased with increasing $\mathrm{HCl}$ concentration at higher regions. Given that $\mathrm{Pd}(\mathrm{II})$ is a relatively ligand-exchangeable ion among the $\mathrm{PGMs}$, the extraction behavior at low $\mathrm{HCl}$ concentration is probably due to chloride ions suppressing the typical ligand exchange reaction [5,7]. Additionally, at high $\mathrm{HCl}$ concentrations, the extraction percentage increased with increasing $\mathrm{HCl}$ concentration because of the anion exchange reaction via coulombic interaction associated with the protonation of the extractant [5,7]. Further, $\operatorname{Rh}(\mathrm{III})$ and $\operatorname{Ir}(\mathrm{III})$ were hardly extracted in any extraction system, except that the extraction percentages of $\mathrm{Rh}(\mathrm{III})$ and $\mathrm{Ir}(\mathrm{III})$ by MonoBU were $16 \%$ and $31 \%$, respectively, at $\mathrm{HCl}$ concentrations of 3.0-5.0 M.

For base metals, $\mathrm{Fe}(\mathrm{III}), \mathrm{Cu}(\mathrm{II}), \mathrm{Co}(\mathrm{II})$, and $\mathrm{Zn}(\mathrm{II})$ were hardly extracted at $\mathrm{HCl}$ concentration of $0.01-1.0 \mathrm{M}$, whereas at $\mathrm{HCl}$ concentration of 1.0-10 M, the extraction percentage increased with increasing $\mathrm{HCl}$ concentration. This phenomenon is due not only to the protonation of the extractant but also to the presence of these metal ions as anionic species such as $\left[\mathrm{FeCl}_{4}\right]^{-},\left[\mathrm{CuCl}_{4}\right]^{2-},\left[\mathrm{CoCl}_{4}\right]^{2-}$, and $\left[\mathrm{ZnCl}_{4}\right]^{2-}$ at high $\mathrm{HCl}$ concentrations $[16,40,41]$. Additionally, it is considered that $\mathrm{Ni}$ (II) and $\mathrm{Pb}$ (II) were hardly extracted because they do not form anionic species with chloride ions [42,43]. 


\subsection{Extraction from SSRs}

\subsubsection{Effect of Shaking Time}

In this section, we investigated the selective extraction of $\mathrm{Pt}(\mathrm{IV})$ from SSRs containing high concentrations of metal ions. Figure 3 shows the effect of shaking time on the extraction and stripping percentages of $\mathrm{Pt}(\mathrm{IV})$ by MonoAA, MonoOA, and MonoBU. For Pt(IV) extraction, the \% Extraction of $\mathrm{Pt}(\mathrm{IV})$ reached the equilibrium in about $3 \mathrm{~h}$ for all extractants and remained constant for more than $20 \mathrm{~h}$. For stripping, the \%Stripping of $\mathrm{Pt}(\mathrm{IV})$ reached the equilibrium in 3-6 h for all extractants. These results suggest that the extractants synthesized in this study are capable of extracting and stripping $\mathrm{Pt}(\mathrm{IV})$ relatively quickly. Based on this result, the shaking time of subsequent extraction and stripping experiments was set to $3 \mathrm{~h}$.

(a)

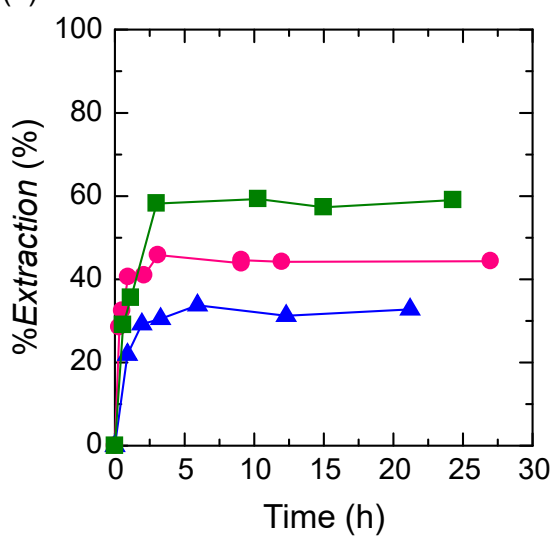

(b)

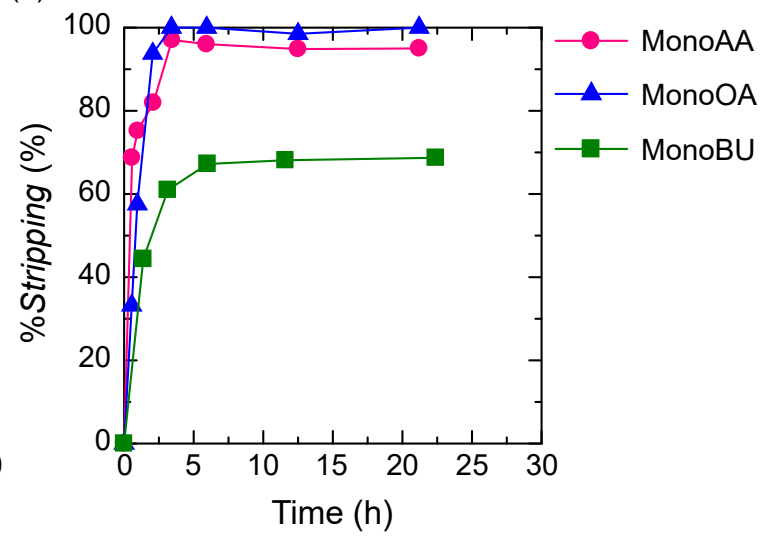

Figure 3. Effect of shaking time on the (a) extraction and (b) stripping percentages of $\mathrm{Pt}(\mathrm{IV})$ by MonoAA, MonoOA, and MonoBU. [Extractant $]_{\text {org, }, \mathrm{i}}=1.0 \mathrm{M}$ in $n$-dodecane/2-ethylhexanol $(80 \mathrm{vol} \% / 20 \mathrm{vol} \%),[\mathrm{Pt}(\mathrm{IV})]_{\mathrm{aq}, \mathrm{i}}=0.243 \mathrm{M},[\operatorname{Ir}(\mathrm{III})]_{\mathrm{aq}, \mathrm{i}}=4.92 \times 10^{-3} \mathrm{M},[\operatorname{Rh}(\mathrm{III})]_{\mathrm{aq}, \mathrm{i}}=0.117 \mathrm{M}$, $[\mathrm{Cu}(\mathrm{II})]_{\mathrm{aq}, \mathrm{i}}=0.291 \mathrm{M},[\mathrm{HCl}]_{\mathrm{aq}, \mathrm{i}}=2.0 \mathrm{M}$.

\subsubsection{Pt(IV) Separation from SSRs}

The extraction and separation ability of Pt(IV) from SSRs by the four extractants synthesized in this study was investigated. Briefly, $2.0 \mathrm{M} \mathrm{HCl}$ solutions containing approximately $0.274 \mathrm{M}(53.4 \mathrm{~g} / \mathrm{L}), 8.24 \times 10^{-3} \mathrm{M}(1.58 \mathrm{~g} / \mathrm{L}), 0.115 \mathrm{M}(11.8 \mathrm{~g} / \mathrm{L})$, and $0.268 \mathrm{M}$ $(17.0 \mathrm{~g} / \mathrm{L})$ of $\mathrm{Pt}(\mathrm{IV}), \mathrm{Ir}(\mathrm{III}), \mathrm{Rh}(\mathrm{III})$, and $\mathrm{Cu}(\mathrm{II})$ were employed as SSRs. For comparison, TOA, TBP, DBC, and MIBK were used as conventional commercial extractants. Figure 4 shows the extraction percentage of $\mathrm{Pt}(\mathrm{IV}), \mathrm{Ir}(\mathrm{III}), \mathrm{Rh}(\mathrm{III})$, and $\mathrm{Cu}(\mathrm{II})$ from the SSRs by these eight extractants.

In terms of the extraction ability of $\mathrm{Pt}(\mathrm{IV})$, the following order was observed: TOA > MonoBU $\approx$ MonoAA $>$ MonoOA $>$ TBP, DBC, MIBK, BisAA. This difference in extraction ability is thought to be due to differences in the extraction mechanism. TOA, a tertiary amine, is readily protonated under acidic conditions and extracts $\mathrm{Pt}(\mathrm{IV})$ through an anion exchange reaction with $\left[\mathrm{PtCl}_{6}\right]^{2-}$ via coulombic interaction [5,7-9]. Meanwhile, the carbonyl oxygen atoms of secondary amide and urea groups are protonated only under relatively high acidic conditions [15,36-39]. Additionally, the results of Figure 2 and previous studies [32] suggest that the Pt(IV) extraction using MonoAA, MonoOA, and MonoBU also involves hydrogen bonding, which is a relatively weak interaction. Thus, MonoAA, MonoOA, and MonoBU were considered to have lower extraction ability of $\mathrm{Pt}(\mathrm{IV})$ than TOA. BisAA, TBP, DBC, and MIBK hardly extracted Pt(IV) from the SSRs, and this result agrees with Figure 2 and previous reports [5,7-9,35,44]. 


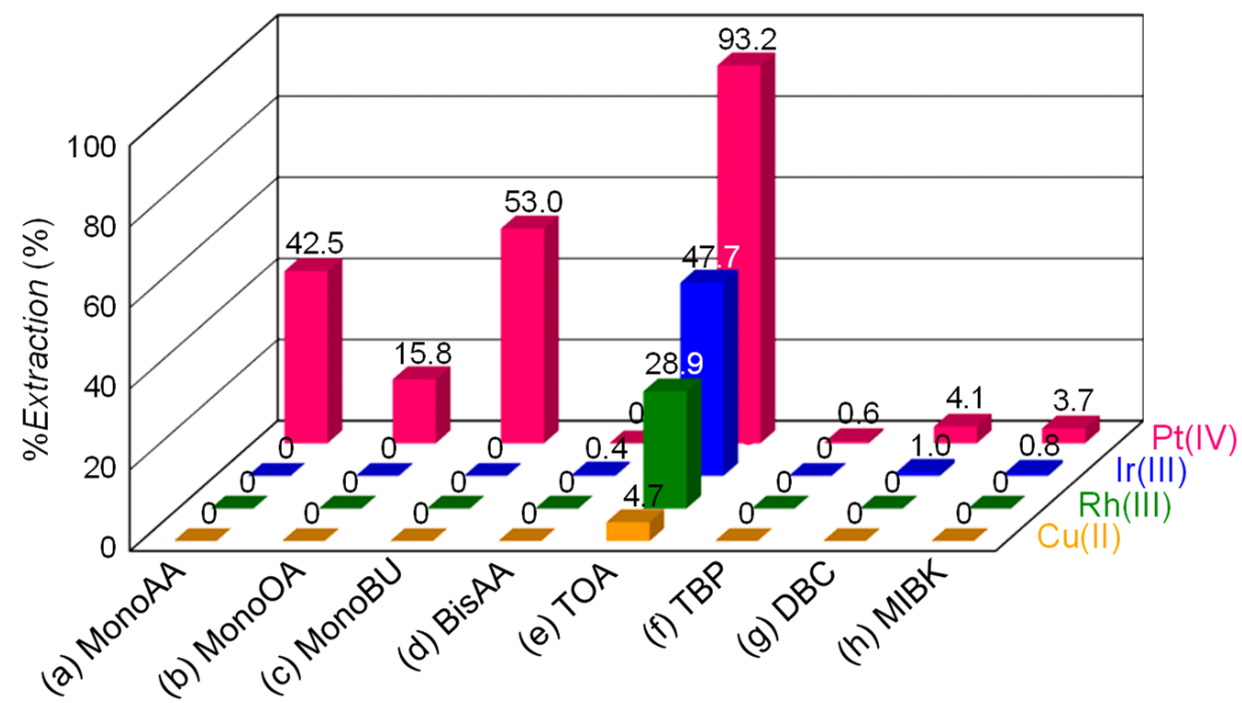

Figure 4. Extraction percentage of $\mathrm{Pt}(\mathrm{IV}), \mathrm{Ir}(\mathrm{III}), \mathrm{Rh}(\mathrm{III})$, and $\mathrm{Cu}(\mathrm{II})$ from SSRs by (a) MonoAA, (b) MonoOA, (c) MonoBU, (d) BisAA, (e) TOA, (f) TBP, (g) DBC, (h) MIBK. [Extractant $]_{\text {org, }, \mathrm{i}}=1.0 \mathrm{M}$ in $n$-dodecane/2-ethylhexanol (80 vol\%/20 vol\%), $[\mathrm{Pt}(\mathrm{IV})]_{\mathrm{aq}, \mathrm{i}}=0.270 \mathrm{M},[\operatorname{Ir}(\mathrm{III})]_{\mathrm{aq}, \mathrm{i}}=9.40 \times 10^{-3} \mathrm{M}$, $[\mathrm{Rh}(\mathrm{III})]_{\mathrm{aq}, \mathrm{i}}=0.109 \mathrm{M},[\mathrm{Cu}(\mathrm{II})]_{\mathrm{aq}, \mathrm{i}}=0.248 \mathrm{M},[\mathrm{HCl}]_{\mathrm{aq}, \mathrm{i}}=2.0 \mathrm{M}$.

For Pt(IV) selectivity, MonoAA, MonoOA, and MonoBU revealed higher selectivity than other extractants. Transition metal ions including PGMs form anionic chlorospecies due to strong interactions with $\mathrm{Cl}^{-}[5,7]$. However, $\mathrm{Cu}(\mathrm{II})$ forms anion complexes such as $\left[\mathrm{CuCl}_{4}\right]^{2-}$ only under extreme conditions, such as chloride ion concentrations of 6.0 M or higher [40,42]. Accordingly, $\mathrm{Pt}(\mathrm{IV}), \mathrm{Ir}(\mathrm{III}), \mathrm{Rh}(\mathrm{III})$, and $\mathrm{Cu}(\mathrm{II})$ exist as $\left[\mathrm{PtCl}_{6}\right]^{2-}$, $\left[\mathrm{IrCl}_{5}\left(\mathrm{H}_{2} \mathrm{O}\right)\right]^{2-},\left[\mathrm{IrCl}_{6}\right]^{3-},\left[\mathrm{RhCl}_{5}\left(\mathrm{H}_{2} \mathrm{O}\right)\right]^{2-},\left[\mathrm{RhCl}_{6}\right]^{3-}$, and $\mathrm{Cu}^{2+}$, respectively, in $2.0 \mathrm{M} \mathrm{Cl}^{-}$ solution $[5,7,40,42]$. Moreover, the tendency of the chloro-anionic species to form ion pairs with cationic ligands is $\left[\mathrm{MCl}_{6}\right]^{2-}>>\left[\mathrm{MCl}_{6}\right]^{3-}>\left[\mathrm{MCl}_{5}\left(\mathrm{H}_{2} \mathrm{O}\right)\right]^{2-}$, where $\mathrm{M}$ denotes the respective metal ions [5,7]. This order is based on the charge density of the chloro-anionic species, i.e., lower negatively charged species will preferentially form ion pairs with a positively charged species compared with higher negatively charged species. Considering these factors, it is probable that the high $\mathrm{Pt}(\mathrm{IV})$ selectivity is due to the relatively weak extraction ability of MonoAA, MonoOA, and MonoBU, as well as the presence of $\operatorname{Ir}(\mathrm{III})$ and $\mathrm{Rh}(\mathrm{III})$ as more inert species. Therefore, the almost zero extraction percentage of $\mathrm{Ir}(\mathrm{III}), \mathrm{Rh}(\mathrm{III})$, and $\mathrm{Cu}(\mathrm{II})$ by MonoAA, MonoOA, and MonoBU is considered a significant advantage in the actual hydrometallurgical separation process.

\subsubsection{Effect of Diluent Composition of the Organic Phase}

For stable operation of the actual hydrometallurgical separation process, not only high extraction efficiency but also the absence of a third phase is required [45-48]. In this section, we investigated the effect of the mixing ratio of the diluents $n$-dodecane and 2-ethylhexanol on the extraction of $\mathrm{Pt}(\mathrm{IV})$. Figure 5 shows the extraction percentages of $\mathrm{Pt}(\mathrm{IV})$ using MonoAA, MonoOA, and MonoBU in various $n$-dodecane/2-ethylhexanol ratios. The addition of 2-ethylhexanol suppressed the formation of the third phase in all extraction systems. When the ratio of 2-ethylhexanol in the diluent was increased, the extraction percentage of $\mathrm{Pt}(\mathrm{IV})$ decreased from $55 \%$ to $32 \%$ for MonoAA. Further, the addition of more than $30 \mathrm{vol} \%$ 2-ethylhexanol suppressed the formation of the third phase. Regarding MonoOA, when more than $20 \mathrm{vol} \%$ of 2-ethylhexanol was added, the extraction percentage of $\mathrm{Pt}(\mathrm{IV})$ remained almost constant at about $25 \%$, and no third phase was formed. In the case of MonoBU, more than $50 \mathrm{vol} \%$ 2-ethylhexanol was required to suppress the third phase formation. The addition of slightly polar higher alcohols such as 2-ethylhexanol, which increased the solubility of the extracted complex in the organic phase, may have suppressed the third phase formation [45-48]. 


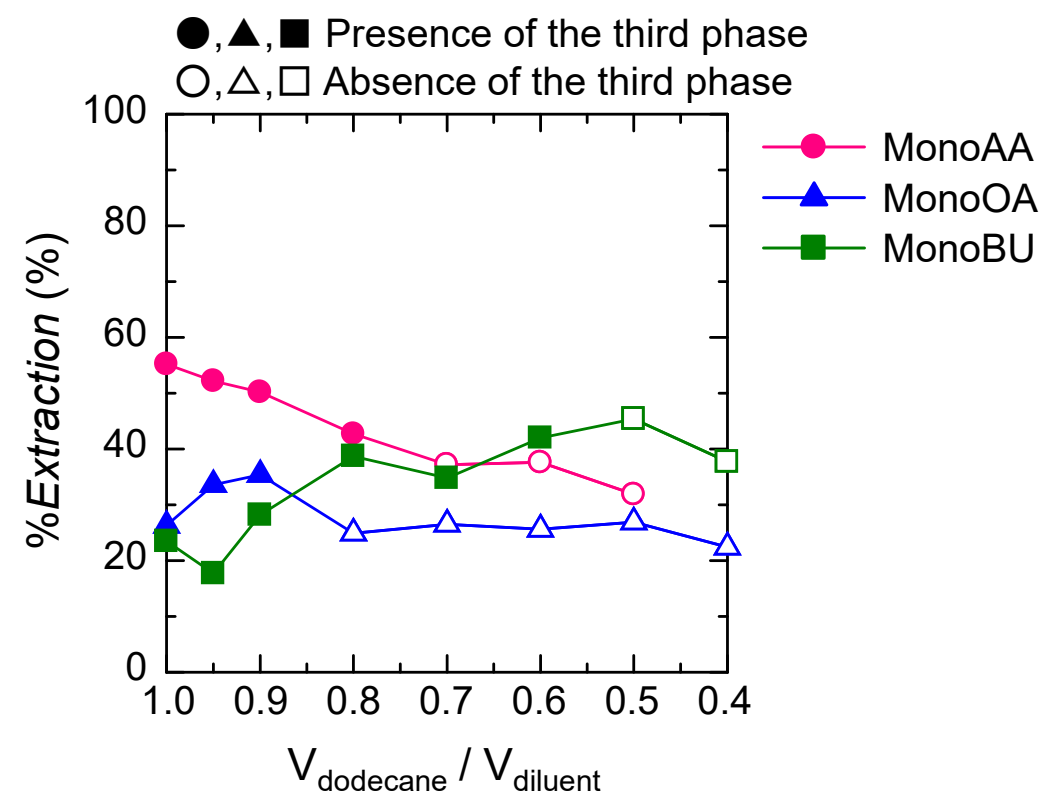

Figure 5. Effect of composition of the organic phase diluent on the extraction percentage of $\mathrm{Pt}(\mathrm{IV})$ by MonoAA, MonoOA, and MonoBU. [Extractant $]_{\mathrm{org}, \mathrm{i}}=1.0 \mathrm{M}$ in $n$-dodecane/2ethylhexanol (100 vol\%/0 vol\% $-40 \mathrm{vol} \% / 60 \mathrm{vol} \%),[\mathrm{Pt}(\mathrm{IV})]_{\mathrm{aq}, \mathrm{i}}=0.292 \mathrm{M},[\operatorname{Ir}(\mathrm{III})]_{\mathrm{aq}, \mathrm{i}}=9.64 \times 10^{-3}$ $\mathrm{M},[\mathrm{Rh}(\mathrm{III})]_{\mathrm{aq}, \mathrm{i}}=0.116 \mathrm{M},[\mathrm{Cu}(\mathrm{II})]_{\mathrm{aq}, \mathrm{i}}=0.262 \mathrm{M},[\mathrm{HCl}]_{\mathrm{aq}, \mathrm{i}}=2.0 \mathrm{M}$.

\subsubsection{Effect of Phase Ratio of the Organic and Aqueous Phases}

Figure 6 shows the effect of the phase ratio of organic to aqueous phases on the extraction of $\mathrm{Pt}(\mathrm{IV})$ by MonoAA, MonoOA, and MonoBU. In all extraction systems, the extraction percentage of $\mathrm{Pt}(\mathrm{IV})$ increased with the phase ratio of the organic phase. In the MonoAA and MonoBU systems, the third phase was formed in all volume ratios of the diluent, whereas in the MonoOA system, no third phase was formed. This is thought to be due to MonoOA's longer alkyl chains than other extractants, which results in higher solubility MonoOA and Pt(IV) extracted complexes in the organic phase.

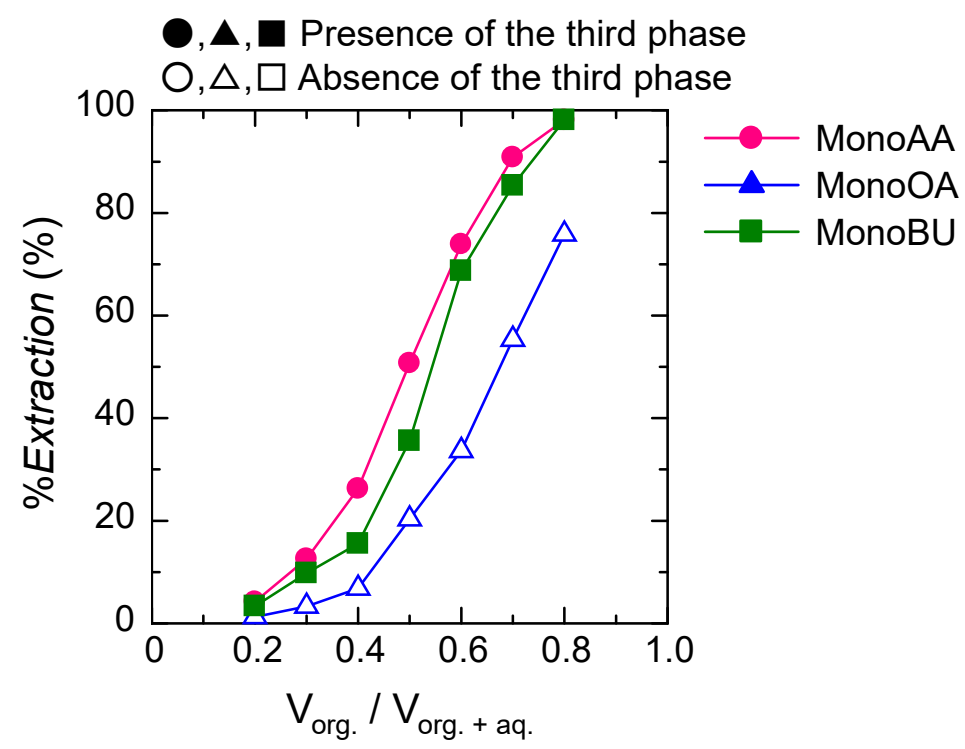

Figure 6. Effect of phase ratio between organic and aqueous phases on the extraction percentage of $\mathrm{Pt}(\mathrm{IV})$ by MonoAA, MonoOA, and MonoBU. [Extractant $]_{\text {org, }, \mathrm{i}}=1.0 \mathrm{M}$ in $n$-dodecane/2-ethylhexanol $(80 \mathrm{vol} \% / 20 \mathrm{vol} \%),[\mathrm{Pt}(\mathrm{IV})]_{\mathrm{aq}, \mathrm{i}}=0.281 \mathrm{M},[\operatorname{Ir}(\mathrm{III})]_{\mathrm{aq}, \mathrm{i}}=9.64 \times 10^{-3} \mathrm{M},[\operatorname{Rh}(\mathrm{III})]_{\mathrm{aq}, \mathrm{i}}=0.116 \mathrm{M}$, $[\mathrm{Cu}(\mathrm{II})]_{\mathrm{aq}, \mathrm{i}}=0.262 \mathrm{M},[\mathrm{HCl}]_{\mathrm{aq}, \mathrm{i}}=2.0 \mathrm{M}, \mathrm{V}_{\mathrm{org}}: \mathrm{V}_{\mathrm{aq}}=2: 8-8: 2$. 


\subsubsection{Effect of $\mathrm{Pt}(\mathrm{IV})$ Concentration}

We studied the effects of initial Pt(IV) and extractant concentrations on Pt(IV) extraction to confirm the conditions for the third phase formation in the extraction of $\mathrm{Pt}(\mathrm{IV})$. Figure 7 shows a plot of the equilibrium $\mathrm{Pt}(\mathrm{IV})$ concentration in the organic phase against the initial $\mathrm{Pt}(\mathrm{IV})$ concentration in the aqueous phase. Here, $n$-dodecane/2-ethylhexanol (80 vol\%/20 vol\%) was used as a diluent.
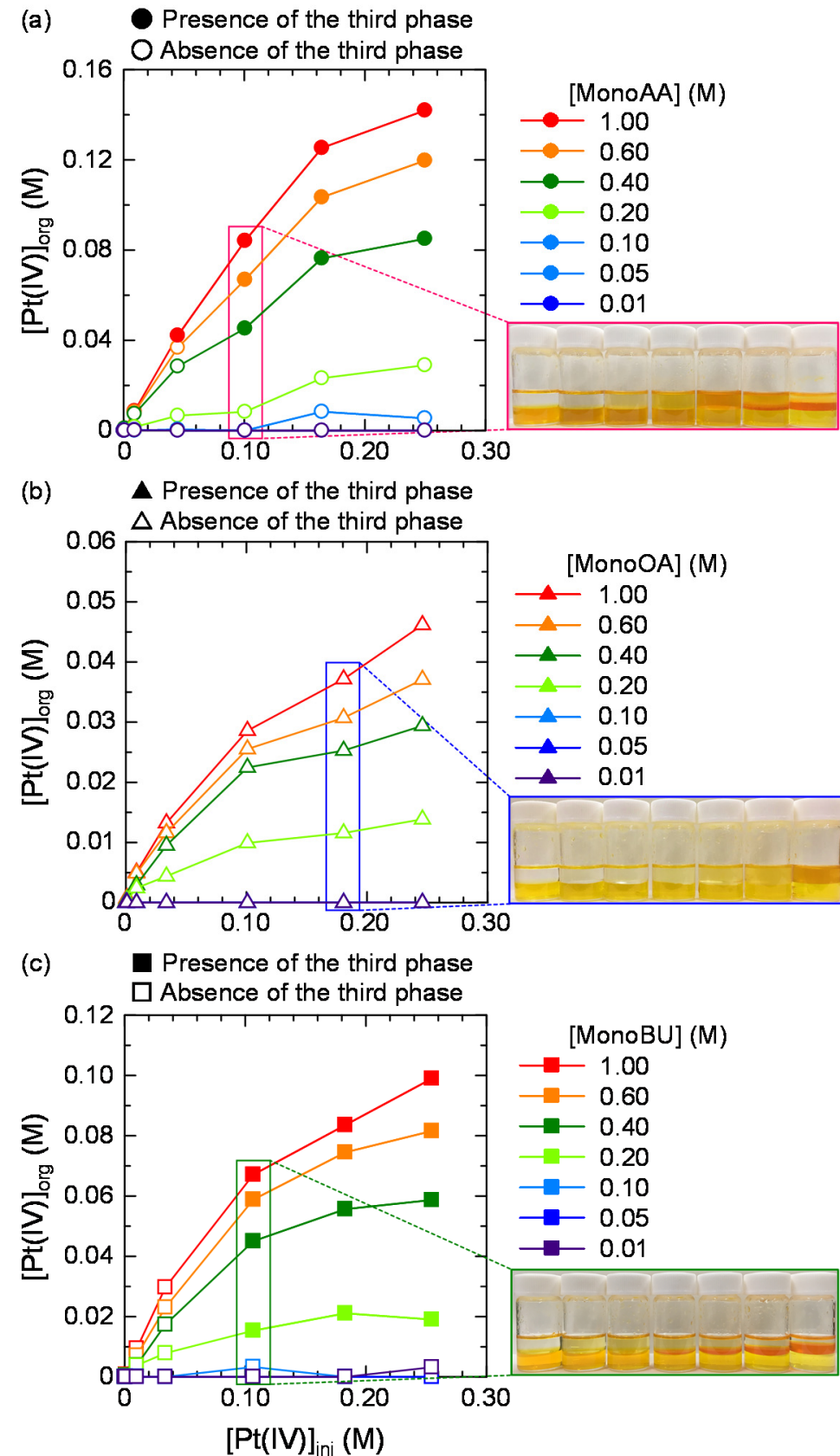

Figure 7. Effect of initial $\mathrm{Pt}(\mathrm{IV})$ and extractant concentrations on the third phase formation during $\mathrm{Pt}(\mathrm{IV})$ extraction by (a) MonoAA, (b) MonoOA, and (c) MonoBU. [Extractant $]_{\text {org, },}=0.01-1.0 \mathrm{M}$ in $n$-dodecane/2-ethylhexanol (80 vol\%/20 vol\%), $[\mathrm{Pt}(\mathrm{IV})]_{\mathrm{aq}, \mathrm{i}}=0.001-0.274 \mathrm{M},[\mathrm{HCl}]_{\mathrm{aq}, \mathrm{i}}=2.0 \mathrm{M}$.

A common observation across all extraction systems is that the $\mathrm{Pt}(\mathrm{IV})$ concentration in the organic phase increases with the initial $\mathrm{Pt}(\mathrm{IV})$ and the extractant concentrations. Figure 7a shows that the third phase was in the MonoAA system when the initial $\mathrm{Pt}(\mathrm{IV})$ and extractant concentrations were above 0.05 and $0.40 \mathrm{M}$, respectively. Further, no third phase was formed under any conditions in the MonoOA system (Figure $7 \mathrm{~b}$ ). This could be 
due to MonoOA's long alkyl chains improving the solubility of the extracted complex in the diluent, which agrees well with the trend in Figure 6. Moreover, Figure 7c shows that the third phase was formed in the MonoBU system when the initial Pt(IV) and extractant concentrations were above 0.10 and $0.20 \mathrm{M}$, respectively. The order of $\mathrm{Pt}(\mathrm{IV})$ extraction capacity is MonoAA > MonoBU > MonoOA; however, MonoOA has the advantage of being less likely to form the third phase, which is vital for the stability of the separation process.

\subsection{Stripping Test}

\subsubsection{Stripping of $\mathrm{Pt}(\mathrm{IV})$}

A stripping experiment from the Pt(IV) loaded organic phase was conducted. Table 1 lists the stripping percentage of $\mathrm{Pt}(\mathrm{IV})$ from the $\mathrm{Pt}(\mathrm{IV})$ loaded organic phase using MonoAA, MonoOA, and MonoBU. In this study, $5.0 \mathrm{M} \mathrm{HCl}$ and $5.0 \mathrm{M} \mathrm{HNO}_{3}$ were used as acidic stripping reagents, water as a neutral stripping reagent, and $0.1 \mathrm{M} \mathrm{NH}_{3}$ solution and $0.1 \mathrm{M}$ $\mathrm{NaOH}$ solution as stripping reagents.

Table 1. Stripping percentage of $\mathrm{Pt}(\mathrm{IV})$ from $\mathrm{Pt}(\mathrm{IV})$ loaded organic phase by MonoAA, MonoOA, and MonoBU. [Extractant $]_{\mathrm{org}, \mathrm{i}}=1.0 \mathrm{M}$ in $n$-dodecane/2-ethylhexanol $(80 \mathrm{vol} \% / 20 \mathrm{vol} \%)$, $[\mathrm{Pt}(\mathrm{IV})]_{\mathrm{aq}, \mathrm{i}}=0.256 \mathrm{M},[\operatorname{Ir}(\mathrm{III})]_{\mathrm{aq}, \mathrm{i}}=9.54 \times 10^{-3} \mathrm{M},[\mathrm{Rh}(\mathrm{III})]_{\mathrm{aq}, \mathrm{i}}=0.112 \mathrm{M},[\mathrm{Cu}(\mathrm{II})]_{\mathrm{aq}, \mathrm{i}}=0.270 \mathrm{M}$, $[\mathrm{HCl}]_{\mathrm{aq}, \mathrm{i}}=2.0 \mathrm{M}$. \% Extraction of $\mathrm{Ir}(\mathrm{III}), \mathrm{Rh}(\mathrm{III})$, and $\mathrm{Cu}(\mathrm{II})$ were $0 \%$ in any extraction systems.

\begin{tabular}{cccc}
\hline \multirow{2}{*}{ Stripping Reagent } & \multicolumn{3}{c}{ \%Stripping of Pt(IV) (\%) } \\
\cline { 2 - 4 } & MonoAA $^{\mathbf{1}}$ & MonoOA $^{\mathbf{2}}$ & MonoBU $^{\mathbf{3}}$ \\
\hline $5.0 \mathrm{M} \mathrm{HCl}$ & 13.8 & 9.3 & 4.5 \\
$\mathrm{M} \mathrm{HNO}_{3}$ & 53.4 & 81.3 & 73.7 \\
$\mathrm{Water}^{1} \mathrm{M} \mathrm{NH}_{3}$ & 59.3 & 74.8 & 68.1 \\
$0.1 \mathrm{M} \mathrm{NaOH}$ & 60.0 & 78.8 & 70.2 \\
& 60.4 & 69.6 & 64.3 \\
\hline
\end{tabular}

$1 \%$ Extraction of $\mathrm{Pt}(\mathrm{IV})$ by MonoAA is $42.7 \% .{ }^{2}$ \% Extraction of $\mathrm{Pt}(\mathrm{IV})$ by MonoOA is $22.8 \% .{ }^{3} \%$ Extraction of $\mathrm{Pt}(\mathrm{IV})$ by MonoBU is $61.0 \%$.

For water, the stripping percentages of MonoAA, MonoOA, and MonoBU systems were $59.3 \%, 74.8 \%$, and $68.1 \%$, respectively. The stripping of PGM ions requires a highly concentrated acidic or basic aqueous solution and a sulfur-containing reagent such as thiourea [35]. Although the stripping percentage is not quantitative, the fact that $\mathrm{Pt}(\mathrm{IV})$ can be stripped using only water is a major advantage of these extraction systems from the perspective of industrial use and reduced environmental impact. Although this is a hypothetical step that requires further investigation, the stripping of $\mathrm{Pt}(\mathrm{IV})$ by water alone could be due to the deprotonation of the extractants and $\mathrm{Pt}(\mathrm{IV})$ extraction via relatively weak interactions such as hydrogen bonding interactions. The $\mathrm{Pt}(\mathrm{IV})$ stripping percentage was observed in the following order: MonoOA > MonoBU > MonoAA, which was the reverse of the order of extraction ability in Figures 2 and 4.

For the basic stripping reagents, $0.1 \mathrm{M} \mathrm{NH}_{3}$ and $0.1 \mathrm{M} \mathrm{NaOH}$ aqueous solutions, the stripping percentages of $\mathrm{Pt}(\mathrm{IV})$ in MonoAA, MonoOA, and MonoBU systems were about $60 \%, 70-79 \%$, and $64-70 \%$, respectively. There was no significant difference was observed between the $\mathrm{NH}_{3}$ and $\mathrm{NaOH}$ solutions.

Regarding the acidic stripping reagents, $\mathrm{HNO}_{3}$ was clearly more effective than $\mathrm{HCl}$ in stripping $\mathrm{Pt}(\mathrm{IV})$ in all extraction systems. The fact that $5.0 \mathrm{M} \mathrm{HCl}$ barely stripped $\mathrm{Pt}(\mathrm{IV})$ corresponds to the result in Figure 2 that $\mathrm{Pt}(\mathrm{IV})$ was well extracted from $5.0 \mathrm{M} \mathrm{HCl}$ in all extraction systems. In the case of $\mathrm{HNO}_{3}$ as a stripping reagent, $\mathrm{Pt}(\mathrm{IV})$ was possibly stripped due to the extraction of $\mathrm{HNO}_{3}$ molecules into the organic phase and the change in $\mathrm{Pt}(\mathrm{IV})$ speciation.

\subsubsection{Effect of Settling Time of Organic Phase after Pt(IV) Loading}

In the actual hydrometallurgical separation process, there are situations where the stripping process cannot be performed immediately after the forward extraction. Thus, it is necessary to verify whether stripping can be performed stably even if the organic phase 
containing metal ions has settled for a while after the forward extraction. Figure 8 shows the effect of settling time of the Pt(IV) loaded organic phase on the stripping percentage of $\mathrm{Pt}(\mathrm{IV})$ using MonoAA. Here, we only examined the MonoAA extraction system, which has the highest $\mathrm{Pt}(\mathrm{IV})$ extraction ability of the three extractants, as a representative. Water was used as a stripping reagent. Figure 8 also shows that despite the $\mathrm{Pt}(\mathrm{IV})$ loaded organic phase was settled for $300 \mathrm{~h}$, the stripping percentage was $81 \%$. This suggests that the stripping process can be performed stably at least within $300 \mathrm{~h}$ after $\mathrm{Pt}(\mathrm{IV})$ extraction. Note that this \%Stripping deviates slightly from the results in Table 1 . This may be due to the difference in the initial concentration of $\mathrm{Pt}(\mathrm{IV})$ in each experiment, although a more detailed study is needed.

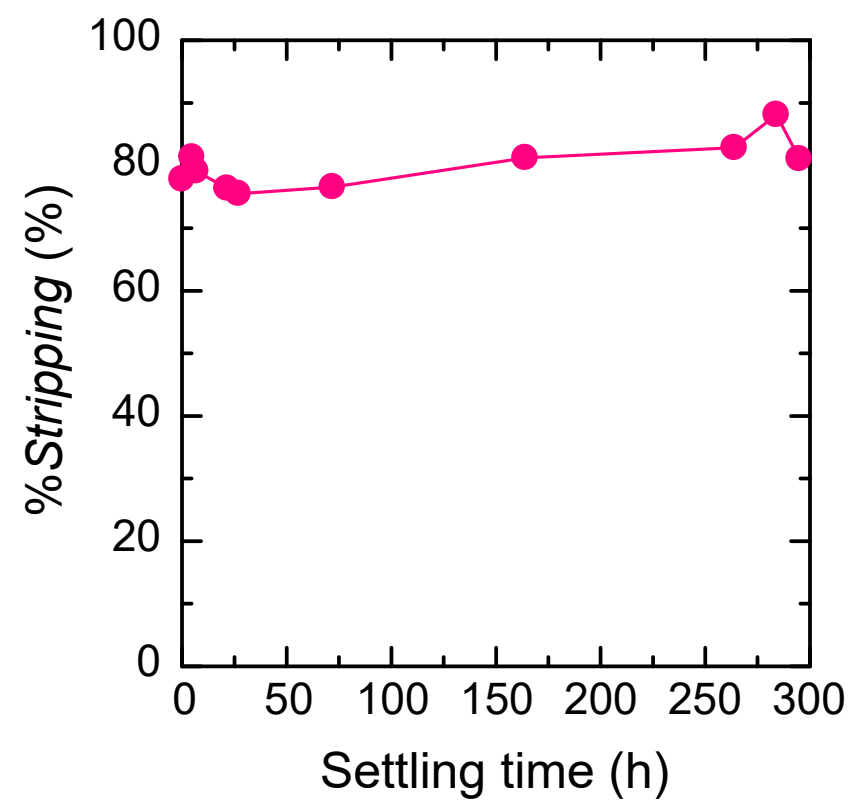

Figure 8. Effect of settling time of the Pt(IV) loaded organic phase on the stripping percentage of $\mathrm{Pt}(\mathrm{IV})$ by MonoAA. [MonoAA] $]_{\mathrm{org}, \mathrm{i}}=1.0 \mathrm{M}$ in $n$-dodecane/2-ethylhexanol $(80 \mathrm{vol} \% / 20 \mathrm{vol} \%)$, $[\mathrm{Pt}(\mathrm{IV})]_{\mathrm{aq}, \mathrm{i}}=0.295 \mathrm{M},[\operatorname{Ir}(\mathrm{III})]_{\mathrm{aq}, \mathrm{i}}=9.83 \times 10^{-3} \mathrm{M},[\mathrm{Rh}(\mathrm{III})]_{\mathrm{aq}, \mathrm{i}}=0.119 \mathrm{M},[\mathrm{Cu}(\mathrm{II})]_{\mathrm{aq}, \mathrm{i}}=0.270 \mathrm{M}$, $[\mathrm{HCl}]_{\mathrm{aq}, \mathrm{i}}=2.0 \mathrm{M}$. Stripping reagent: water.

\section{Conclusions}

In this study, the extraction and separation of Pt(IV) from SSRs by simple secondary amides and urea extractants were evaluated to explore the applicability of these extractants to the actual hydrometallurgical separation process. In the extraction of $\mathrm{Pt}(\mathrm{IV})$ from low $\mathrm{HCl}$ concentration by MonoAA, MonoOA, and MonoBU, Pt(IV) was extracted only via the hydrogen bonding interaction to $\left[\mathrm{PtCl}_{6}\right]^{2-}$ by $\mathrm{N}-\mathrm{H}$ moieties of secondary amide and urea groups. Despite the presence of numerous metal ions, MonoAA, MonoOA, and MonoBU exhibited high Pt(IV) selectivity in the Pt(IV) extraction from the SSRs, though their Pt(IV) extraction ability was lower than TOA. MonoAA had the highest Pt(IV) extraction capacity compared with MonoOA and MonoBU. However, MonoOA had a lower $\mathrm{Pt}(\mathrm{IV})$ extraction capacity but hardly produced the third phase. In all extraction systems, $\mathrm{Pt}(\mathrm{IV})$ was readily stripped from the $\mathrm{Pt}(\mathrm{IV})$ loaded organic phase using only water. We believe that the detailed investigation of the practical application of the secondary amide and urea extractants developed in this study will help improve the efficiency of the $\mathrm{Pt}$ separation process in the future. 
Supplementary Materials: The following are available online at https:/ / www.mdpi.com/article/10.3 390/separations8090139/s1, Figure S1: ${ }^{1} \mathrm{H}$ NMR spectra of (a) N-(2-ethylhexyl)acetamide (MonoAA), (b) MonoAA exchanged with $\mathrm{D}_{2} \mathrm{O}$, and (c) 2-ethylhexylamine as a starting material, Figure S2: IR spectra of $\mathrm{N}$-(2-ethylhexyl)acetamide (MonoAA), Figure S3: ${ }^{1} \mathrm{H}$ NMR spectra of (a) $\mathrm{N}$-(2-ethylhexyl)octanamide (MonoOA), (b) MonoOA exchanged with $\mathrm{D}_{2} \mathrm{O}$, and (c) 2-ethylhexylamine as a starting material, Figure S4: IR spectra of $N$-(2-ethylhexyl)octanamide (MonoOA), Figure S5: ${ }^{1} \mathrm{H}$ NMR spectra of (a) $N, N$ bis(2-ethylhexyl)acetamide (BisAA), (b) BisAA exchanged with $\mathrm{D}_{2} \mathrm{O}$, and (c) di(2-ethylhexyl)amine as a starting material, Figure S6: IR spectra of $N, N$-bis(2-ethylhexyl)acetamide (BisAA).

Author Contributions: Conceptualization, Y.U. and K.O.; validation, Y.U.; formal analysis, Y.U.; investigation, Y.U.; data curation, Y.U. and K.O.; writing—original draft preparation, Y.U.; writing-review and editing, Y.U., S.M., H.K. and K.O.; supervision, K.O.; funding acquisition, Y.U. and K.O. All authors have read and agreed to the published version of the manuscript.

Funding: This work was supported by the Tanaka Kikinzoku Kogyo K.K. and the Japan Society for the Promotion of Science (Grant-in-Aid for JSPS Research Fellow Grant Number 14J04076).

Data Availability Statement: Data are available from the authors upon the reasonable request.

Acknowledgments: The NMR measurements for compound identification were conducted at the Analytical Research Center for Experimental Sciences, Saga University.

Conflicts of Interest: There are no conflict to declare.

\section{References}

1. Cooper, J.; Beecham, J. A Study of Platinum Group Metals in Three-Way Autocatalysts. Platin. Met. Rev. 2013, 57, 281-288. [CrossRef]

2. Hagelüken, C. Recycling the Platinum Group Metals: A European Perspective. Platin. Met. Rev. 2012, 56, 29-35. [CrossRef]

3. Glaister, B.J.; Mudd, G.M. The Environmental Costs of Platinum-PGM Mining and Sustainability: Is the Glass Half-Full or Half-Empty? Miner. Eng. 2010, 23, 438-450. [CrossRef]

4. Holton, O.T.; Stevenson, J.W. The role of platinum in proton exchange membrane fuel cells. Platin. Met. Rev. 2013, 57, 259-271. [CrossRef]

5. Bernardis, F.L.; Grant, R.A.; Sherrington, D.C. A Review of Methods of Separation of the Platinum-Group Metals through Their Chloro-Complexes. React. Funct. Polym. 2005, 65, 205-217. [CrossRef]

6. U.S. Geological Survey. Mineral Commodity Summaries 2020: U.S. Geological Survey; U.S. Geological Survey: Reston, VA, USA, 2020; ISBN 978-1-4113-4362-7.

7. Narita, H.; Kasuya, R.; Suzuki, T.; Motokawa, R.; Tanaka, M. Precious Metal Separations. Ency. Inorg. Bioinorg. Chem. 2020, eibc2756, 1-28. [CrossRef]

8. Jha, M.K.; Gupta, D.; Lee, J.-C.; Kumar, V.; Jeong, J. Solvent Extraction of Platinum using Amine Based Extractants in Different Solutions: A review. Hydrometallurgy 2014, 142, 60-69. [CrossRef]

9. Levitin, G.; Schmuckler, G. Solvent Extraction of Rhodium Chloride from Aqueous Solutions and Its Separation from Palladium and Platinum. React. Funct. Polym. 2003, 54, 149-154. [CrossRef]

10. Costa, M.C.; Almeida, R.; Assunção, A.; Costa, A.M.R.; Nogueira, C.; Paiva, A.P. N,N'-tetrasubstituted succinamides as new molecules for liquid-liquid extraction of Pt(IV) from chloride media. Sep. Purif. Technol. 2016, 158, 409-416. [CrossRef]

11. Paiva, A.P.; Carvalho, G.I.; Costa, M.C.; Costa, A.M.R.; Nogueira, C. The solvent extraction performance of $N, N^{\prime}$-dimethyl-N,N'dibutylmalonamide towards platinum and palladium in chloride media. Sep. Sci. Technol. 2014, 49, 966-973. [CrossRef]

12. Costa, M.C.; Assunção, A.; Costa, A.M.R.; Nogueira, C.; Paiva, A.P. Liquid-Liquid Extraction of Platinum from Chloride Media by $N, N^{\prime}$-Dimethyl- $N, N^{\prime}$ - Dicyclohexyltetradecylmalonamide. Solvent Extr. Ion Exch. 2013, 31, 12-23. [CrossRef]

13. Maeda, M.; Narita, H.; Tokoro, C.; Tanaka, M.; Motokawa, R.; Shiwaku, H.; Yaita, T. Selective Extraction of Pt(IV) over Fe(III) from $\mathrm{HCl}$ with an Amide-Containing Tertiary Amine Compound. Sep. Purif. Technol. 2017, 177, 176-181. [CrossRef]

14. Warr, R.J.; Bell, K.J.; Gadzhieva, A.; Cabot, R.; Ellis, R.J.; Chartres, J.; Henderson, D.K.; Lykourina, E.; Wilson, A.M.; Love, J.B.; et al. A Comparison of the Selectivity of Extraction of $\left[\mathrm{PtCl}_{6}\right]^{2-}$ by Mono-, Bi-, and Tripodal Receptors That Address Its Outer Coordination Sphere. Inorg. Chem. 2016, 55, 6247-6260. [CrossRef]

15. Carson, I.; MacRuary, K.J.; Doidge, E.D.; Ellis, R.J.; Grant, R.A.; Gordon, R.J.; Love, J.B.; Morrison, C.A.; Nichol, G.S.; Tasker, P.A.; et al. Anion Receptor Design: Exploiting Outer-Sphere Coordination Chemistry To Obtain High Selectivity for Chloridometalates over Chloride. Inorg. Chem. 2015, 54, 8685-8692. [CrossRef]

16. Ellis, R.J.; Chartres, J.; Henderson, D.K.; Cabot, R.; Richardson, P.R.; White, F.J.; Schröder, M.; Turkington, J.R.; Tasker, P.A.; Sole, K.C. Design and Function of Pre-Organised Outer-Sphere Amidopyridyl Extractants for Zinc(II) and Cobalt(II) Chlorometallates: The Role of C-H Hydrogen Bonds. Chem. Eur. J. 2012, 18, 7715-7728. [CrossRef] 
17. Warr, R.J.; Westra, A.N.; Bell, K.J.; Chartres, J.; Ellis, R.; Tong, C.; Simmance, T.G.; Gadzhieva, A.; Blake, A.J.; Tasker, P.A.; et al. Selective extraction and transport of the $\left[\mathrm{PtCl}_{6}\right]^{2-}$ anion through outer-sphere coordination chemistry. Chem. Eur. J. 2009, 15, 4836-4850. [CrossRef]

18. Bell, K.J.; Westra, A.N.; Warr, R.J.; Chartres, J.; Ellis, R.; Tong, C.C.; Blake, A.J.; Tasker, P.A.; Schröder, M. Outer-Sphere Coordination Chemistry: Selective Extraction and Transport of the $\left[\mathrm{PtCl}_{6}\right]^{2-}$ Anion. Angew. Chem. Int. Ed. 2008, 47, 1745-1748. [CrossRef]

19. Swiegers, G.F.; Malefetse, T.J. Multiple-Interaction Self-Assembly in Coordination Chemistry. J. Incl. Phenom. Macrocycl. Chem. 2001, 40, 253-264. [CrossRef]

20. Philp, D.; Stoddart, J.F. Self-Assembly in Natural and Unnatural Systems. Angew. Chem. Int. Ed. 1996, 35, 1154-1196. [CrossRef]

21. Ohto, K.; Ueda, Y.; Ohmi, K.; Fujita, M. Platinum extractant, platinum extraction method, and platinum recovery method, JP Patent. JP6556685B2, 7 August 2019.

22. Narita, H.; Morisaku, K.; Tanaka, M. The first effective extractant for trivalent rhodium in hydrochloric acid solution. Chem. Commun. 2008, 5921-5923. [CrossRef]

23. Low, C.M.R.; Broughton, H.B.; Kalindjian, S.B.; McDonald, I.M. Novel oxathiazinones as gastrin ligands: Unezpected products from the Schotten-Baumann reaction of arylsulphonyl chlorides with derivatives of aspartic acid. Bioorg. Med. Chem. Lett. 1992, 2, 325-330. [CrossRef]

24. Erne, D.; Stojanac, N.; Ammann, D.; Hofstetter, P.; Pretsch, E.; Simon, W. Lipophilic Di- and Triamides as Ionophores for Alkaline Earth Metal Cations. Helv. Chim. Acta 1980, 63, 2271-2279. [CrossRef]

25. Sonntag, N.O.V. The Reactions of Aliphatic Acid Chlorides. Chem. Rev. 1953, 52, 237-416. [CrossRef]

26. Raposo, C.; Almaraz, M.; Martin, M.; Weinrich, V.; Mussóns, L.; Alcázar, V.; Caballero, C.; Morán, J.R. Tris(2-aminoethyl)amine, A Suitable Spacer for Phosphate and Sulfate Receptors. Chem. Lett. 1995, 24, 759-760. [CrossRef]

27. Amendola, V.; Fabbrizzi, L.; Mosca, L. Anion Recognition by Hydrogen Bonding: Urea-Based Receptors. Chem. Soc. Rev. 2010, 39, 3889-3915. [CrossRef]

28. Hay, B.P.; Firman, T.K.; Moyer, B.A. Structural Design Criteria for Anion Hosts: Strategies for Achieving Anion Shape Recognition through the Complementary Placement of Urea Donor Groups. J. Am. Chem. Soc. 2005, 127, 1810-1819. [CrossRef]

29. Koevoets, R.A.; Versteegen, R.M.; Kooijman, H.; Spek, A.L.; Sijbesma, R.P.; Meijer, E.W. Molecular Recognition in a Thermoplastic Elastomer. J. Am. Chem. Soc. 2005, 127, 2999-3003. [CrossRef] [PubMed]

30. Corbin, P.S.; Zimmerman, S.C.; Thiessen, P.A.; Hawryluk, N.A.; Murray, T.J. Complexation-Induced Unfolding of Heterocyclic Ureas. Simple Foldamers Equilibrate with Multiply Hydrogen-Bonded Sheetlike Structures. J. Am. Chem. Soc. 2001, 123, 10475-10488. [CrossRef]

31. Etter, M.C.; Lipkowska, Z.U.; Ebrahimi, M.Z.; Panunto, T.W. Hydrogen Bond Directed Cocrystallization and Molecular Recognition Properties of Diarylureas. J. Am. Chem. Soc. 1990, 112, 8415-8426. [CrossRef]

32. Pang, G.; Morisada, S.; Kawakita, H.; Hanamoto, T.; Umecky, T.; Ohto, K.; Song, X.-M. Allosteric extraction of a second gallium anion assisted by the first, loaded onto a fluorinated secondary amide reagent. Sep. Purif. Technol. 2021, 119036, In Press. [CrossRef]

33. Ueda, Y.; Morisada, S.; Kawakita, H.; Ohto, K. High extraction ability and selectivity of a tripodal pivalamide derivative for Pt(IV) from hydrochloric acid solutions. Sep. Sci. Technol. 2016, 51, 2700-2707. [CrossRef]

34. Ueda, Y.; Morisada, S.; Kawakita, H.; Wenzel, M.; Weigand, J.J.; Ohto, K. Effective extraction of Pt(IV) as [PtCl $\left.]_{6}\right]^{2-}$ from hydrochloric acid using a simple urea extractant. Sep. Purif. Technol. 2021, 277, 119456. [CrossRef]

35. Cox, M. Solvent Extraction in Hydrometallurgy. In Solvent Extraction Principles and Practice, 2nd ed.; Rydberg, J., Cox, M., Musikas, C., Choppin, G.R., Eds.; Marcel Dekker Inc.: New York, NY, USA, 2004; pp. 455-505.

36. Clement, O.; Rapko, B.M.; Hay, B.P. Structural Aspects of Metal-Amide Complexes. Coord. Chem. Rev. 1998, 170, 203-243. [CrossRef]

37. Valentine, B.; Amour, T.E.S.; Fiat, D. A ${ }^{17}$ O NMR Study of the Protonation of Urea. Org. Magn. Reson. 1984, 22, 697-700. [CrossRef]

38. Doidge, E.D.; Carson, I.; Tasker, P.A.; Ellis, R.J.; Morrison, C.A.; Love, J.B. A Simple Primary Amide for the Selective Recovery of Gold from Secondary Resources. Angew. Chem. Int. Ed. 2016, 26, 12436-12439. [CrossRef]

39. Ortet, O.; Santos, M.S.C.S.; Paiva, A.P. Palladium(II) and $N, N^{\prime}$-dimethyl- $N, N^{\prime}$-dicyclohexylthiodiglycolamide-The extracted species from concentrated chloride solutions. Sep. Purif. Technol. 2016, 170, 1-9. [CrossRef]

40. Turkington, J.R.; Bailey, P.J.; Love, J.B.; Wilson, A.M.; Tasker, P.A. Exploiting Outer-Sphere Interactions to Enhance Metal Recovery by Solvent Extraction. Chem. Commun. 2013, 49, 1891-1899. [CrossRef]

41. Muñoz-Páez, A.; Pappalardo, R.R.; Marcos, E.S. Determination of the Second Hydration Shell of $\mathrm{Cr}^{3+}$ and $\mathrm{Zn}^{2+}$ in Aqueous Solutions by Extended X-ray Absorption Fine Structure. J. Am. Chem. Soc. 1995, 117, 11710-11720. [CrossRef]

42. Choppin, G.R. Complexation of Metal Ions. In Solvent Extraction Principles and Practice, 2nd ed.; Rydberg, J., Cox, M., Musikas, C., Choppin, G.R., Eds.; Marcel Dekker Inc.: New York, NY, USA, 2004; pp. 81-107.

43. Roberts, J.E.; Schnitler, J. Ionic Quadrupolar Relaxation in Aqueous Solution: Dynamics of the Hydration Sphere. J. Phys. Chem. 1993, 97, 5410-5417. [CrossRef]

44. Narita, H.; Tanaka, M.; Morisaku, K.; Abe, T. Extraction of Gold(III) in Hydrochloric Acid Solution Using Monoamide Compounds. Hydrometallurgy 2006, 81, 153-158. [CrossRef] 
45. Motokawa, R.; Kobayashi, T.; Endo, H.; Mu, J.; Williams, C.D.; Masters, A.J.; Antonio, M.R.; Heller, W.T.; Nagao, M. A Telescoping View of Solute Architectures in A Complex Fluid System. ACS Cent. Sci. 2019, 5, 85-96. [CrossRef] [PubMed]

46. Ueda, Y.; Kikuchi, K.; Sugita, T.; Motokawa, R. Extraction Performance of a Fluorous Phosphate for $\mathrm{Zr}(\mathrm{IV})$ from $\mathrm{HNO}_{3}$ Solution: Comparison with Tri- $n$-Butyl Phosphate. Solvent Extr. Ion Exch. 2019, 37, 347-359. [CrossRef]

47. Mu, J.; Motokawa, R.; Akutsu, K.; Nishitsuji, S.; Masters, A.J. A Novel Microemulsion Phase Transition: Toward the Elucidation of Third-Phase Formation in Spent Nuclear Fuel Reprocessing. J. Phys. Chem. B 2018, 122, 1439-1452. [CrossRef]

48. Antonio, M.R.; Demars, T.J.; Audras, M.; Ellis, R.J. Third phase inversion, red oil formation, and multinuclear speciation of tetravalent cerium in the tri- $n$-butyl phosphate- $n$-dodecane solvent extraction system. Sep. Sci. Technol. 2018, 53, $1834-1847$. [CrossRef] 